\title{
Penggunaan Antibiotik pada Terapi Demam Tifoid Anak di RSAB Harapan Kita
}

\author{
Amar W Adisasmito
}

Latar belakang. Insidens demam tifoid di Indonesia cukup tinggi ( $>100$ kasus per 100.000 populasi per tahun). Insidens pada anak usia 3-6 tahun adalah 1307 per 100.000 populasi per tahun, dan 1172 pada usia 7-19 tahun. Chloramphenicol sampai saat ini masih merupakan obat pilihan lini pertama untuk terapi demam tifoid pada anak. Antibiotik lain yang dipergunakan untuk terapi demam tifoid anak adalah cotrimoxazole, cefixime dan ceftriaxone.

Tujuan penelitian. Untuk mengevaluasi aspek pemberian antibiotik berdasar berbagai situasi klinis pada terapi demam tifoid anak di ruang Rawat Inap Anak, Departemen Anak, RSAB Harapan Kita, Jakarta.

Metoda. Penelitian dengan desain deskriptif-retrospektif telah dilakukan di Departemen Anak, RSAB Harapan Kita, Jakarta dari 1 Januari hingga 31 Desember 2004 Kriteria inklusi adalah pasien berusia antara 1 bulan sampai 18 tahun, gejala klinis sesuai demam tifoid, dan diagnosis pasti berdasar hasil biakan darah dengan metoda Bac-tect, positif Salmonella typhi. Data diperoleh dari rekapan laboratorium Mikrobiologi dan rekam medik pasien. Korelasi antara ketepatan dosis antibiotik dan lama rawat atau length of stay (LOS) dievaluasi menggunakan program Excell.

Hasil. Sebanyak 31 pasien memenuhi kriteria inklusi. Dari 31 pasien yang diteliti ditemukan bahwa pasien demam tifoid terbanyak adalah usia 6-10 tahun, diikuti usia 1 -5 tahun. Sensitifitas dan spesifisitas uji Widal terhadap uji Bac-tect rendah atau tidak memadai, sehingga uji Widal disini tampaknya bukanlah uji yang baik dalam menegakkan diagnosis demam tifoid. Komplikasi terjadi pada 7 dari 31 pasien, terdiri dari pneumonia dan perdarahan saluran cerna. Ditemukan seluruhnya 1 kasus relaps dari 31 pasien. Tampaknya tidak ada perbedaan yang nyata antara rata-rata lama rawat dan ketepatan dosis antibiotik yang diberikan.

Kesimpulan. Antibiotik terbanyak yang dipakai adalah golongan chloramphenicol dan ceftriaxone intravena. Tidak ada hubungan yang nyata antara pemberian antibiotik dengan dosis kurang terhadap lama rawat pasien, tetapi tentunya masih banyak faktor lain yang dapat mempengaruhinya.

Kata kunci: Demam tifoid, antibiotik, Bac-tect

Alamat korespondensi:

Dr. Amar W. Adisasmito, Sp. A Kelompok Kerja Infeksi SMF Anak RSAB Harapan Kita Jl. Let Jen. S. Parman Kav 87 Jakarta 11420 Tel. 566 8284. Fax. 5601816.

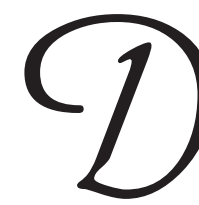

emam tifoid tergolong dalam enteric fever yang berat dan bersifat sistemik sebagai akibat bakteremia yang terjadi. ${ }^{1}$ Sampai saat ini demam tifoid masih merupakan 
masalah kesehatan utama di dunia terutama di negara sedang berkembang seperti Indonesia. Di dunia diperkirakan demam tifoid menyerang 21,6 juta manusia dan menyebabkan 216 ribu kematian pada tahun 2000. Insidens demam tifoid termasuk tinggi (>100 kasus per 100.000 populasi per tahun) di Asia Selatan, Asia Tenggara dan Afrika Selatan. Sebagian besar demam tifoid terjadi pada individu berusia 3 sampai 19 tahun. Di Indonesia insidens demam tifoid pada usia 3-6 tahun adalah 1307 per 100.000 populasi per tahun, sedangkan pada usia 7-19 tahun adalah 1172. Di Indonesia dijumpai 900 ribu pasien demam tifoid per tahun dengan angka kematian lebih dari 20 ribu. $^{2}$

Demam tifoid disebabkan oleh bakteri Gram negatif Salmonella typhi, termasuk golongan Enterobacteriaceae. Bakteri ini terutama berada dalam air dan makanan yang tercemar, karena sumber air minum di beberapa daerah di Indonesia kurang memenuhi syarat. Sayuran dicuci dengan air sungai yang juga dipakai untuk penampungan limbah. Juga perlu diingat makanan dari penjual makanan di pinggir jalan juga dapat tercemar bakteri Salmonella typhi. Jambanpun bisa berakhir di selokan atau sungai. Bakteri ini berasal dari feses manusia yang sedang menderita demam tifoid atau karier Salmonella typhi. Mungkin tidak ada orang Indonesia yang tidak pernah menelan bakteri ini. Bila hanya sedikit tertelan, biasanya orang tidak menderita demam tifoid. Namun bakteri yang sedikit demi sedikit masuk ke tubuh menimbulkan suatu reaksi imun yang dapat dipantau dari darah dikenal dengan reaksi serologi Widal yang positif. ${ }^{2,3}$

Lebih dari $90 \%$ pasien demam tifoid mendapat terapi antibiotik per oral di rumah, tirah baring dan dipantau ketat dengan kontrol ke rumah sakit. Pasien dengan gejala menetap seperti muntah, diare berat atau perut kembung memerlukan perawatan di rumah sakit dan terapi antibiotik parenteral. ${ }^{2}$ Chloramphenicol sampai saat ini masih merupakan obat pilihan lini pertama untuk terapi demam tifoid pada anak. Antibiotik lain yang dipergunakan untuk terapi demam tifoid anak adalah cotrimoxazole dan ceftriaxone. Apabila chloramphenicol tidak dapat diberikan misalnya karena jumlah leukosit <2000/ ul, adanya hipersensitif atau resisten terhadap chloramphenicol, maka cefixime dapat menjadi alternatif terapi dengan efikasi dan toleransi yang baik. ${ }^{1}$

\section{Bahan dan cara}

Penelitian dengan desain deskriptif-retrospektif terhadap pemakaian antibiotik untuk demam tifoid anak telah dilakukan di Departemen Anak, RSAB Harapan Kita, Jakarta, selama 1 tahun sejak 1 Januari - 31 Desember 2004. Subyek yang ikut dalam penelitian berusia antara 1 bulan - 18 tahun dengan diagnosis pasti demam tifoid. Diagnosis klinis demam tifoid ditegakkan berdasarkan pada demam 6 hari atau lebih (suhu $38^{\circ} \mathrm{C}$ atau lebih), mual, muntah, lidah tifoid, perasaan tidak enak di perut (abdominal discomfort), diare atau obstipasi, pembesaran hati dan atau limpa, delirium, dapat juga disertai kesadaran menurun. Diagnosis dikonfirmasi dengan biakan darah terhadap Salmonella typhi dengan metoda Bac-tect, serta uji serologi Widal.

Pemberian chloramphenicol dosis tepat adalah 75 - $100 \mathrm{mg} / \mathrm{kg}$ per hari, dosis maksimal 2000 gr per hari. Dosis tepat ceftriaxone adalah $75-100 \mathrm{mg} / \mathrm{kg}$, dosis maksimal 2000 gr per hari. Nilai Widal positif bila titer $\mathrm{O}=1 / 160$ atau terjadi kenaikan titer $\mathrm{O} 4$ kali dari pemeriksaan yang pertama dengan jarak pemeriksaan satu minggu. Bila nilai titer di bawah nilai yang telah ditentukan termasuk dalam kategori negatif.

Kriteria inklusi ialah 1) semua pasien berusia 1 bulan - 18 tahun dengan catatan medik lengkap, terdiagnosis pasti demam tifoid dengan biakan darah positif terhadap Salmonella typhi dengan metoda Bac-tect, 2) tidak ada riwayat hipersensitifitas terhadap antibiotik, 2) tidak menderita penyakit infeksi lain misalnya tuberkulosis, infeksi saluran kemih, demam berdarah dengue, atau penyakit hati. Semua pasien di bawah usia 1 bulan, catatan medik tidak lengkap, meninggal atau dipulangkan dari rumah sakit sebelum 24 jam perawatan dikeluarkan dari penelitian ini.

Data pasien dengan hasil biakan darah positif Salmonella typhi didapatkan dari data rekapan pemeriksaan biakan darah di laboratorium Mikrobiologi RSAB Harapan Kita. Data pengobatan didapat dari rekam medik, direkam pada formulir profil pengobatan yang telah didesain terlebih dahulu agar memudahkan peneliti pada saat mengevaluasi. Semua data kemudian direkam dalam format Excell dan dianalisa dengan program ini. 


\section{Hasil dan pembahasan}

Pada penelitian ini sesuai dengan yang dikemukakan oleh Klaarje ${ }^{4}$ bahwa penderita dengan jenis kelamin laki-laki lebih banyak (18 pasien) dari pada perempuan (13 pasien). Namun di berbagai penelitian sebelumnya dikemukakan belum ditemukan hubungan antara jenis kelamin dan insiden demam tifoid.

Dari 31 pasien yang diteliti ditemukan kejadian demam tifoid terbanyak usia 6-10 tahun (14 dari 31), diikuti usia $1-5$ tahun (10 dari 31). Hal ini sesuai dengan penelitian oleh Klaartje bahwa angka kejadian tertinggi adalah pada anak usia 5-9 tahun. Pada anak usia 6-10 tahun merupakan masa anak mulai mengenal lingkungan dan bersosialisasi dengan teman-temannya, mereka mulai mengkonsumsi makanan dan minuman yang tidak diketahui dengan jelas kebersihan dari makanan dan minuman tersebut. ${ }^{4}$ Sedangkan Bhan dan Bhatnagar ${ }^{2}$ menyatakan di daerah endemis kasus demam tifoid tersering adalah usia $5-19$ tahun, diikuti dengan usia $1-5$ tahun. Pada penelitian kami angka terendah pada anak usia $<1$ tahun disebabkan karena pola makan yang masih diatur oleh ibu mereka sehingga kemungkinan terjangkitnya lebih kecil. Anak $>10$ tahun sudah lebih memahami akan pentingnya kebersihan terutama pada makanan dan minuman yang mereka konsumsi sehingga angka kejadian tidak terlalu tinggi. Walaupun demikian tidak menutup kemungkinan bagi mereka untuk terjangkit demam tifoid.

Uji sensitifitas terhadap antibiotik dilakukan pada seluruh isolat S. typhi dalam penelitian ini, > 90\% menunjukkan sensitif terhadap seluruh antibiotik yang diujicoba. Lebih dari $90 \%$ strain S. typhi yang diisolasi dari pasien demam tifoid sejak tahun 1993 hingga 2004 di RSAB Harapan Kita ternyata juga masih sensitif terhadap chloramphenicol. Uji sensitifitas tersebut bertujuan sebagai acuan secara invitro bahwa $S$. typhi masih sensitif, walaupun demikian keterkaitan antara sensitifitas secara invitro dengan kesembuhan pasien secara klinis tidak selamanya menunjukkan hal yang searah. Pemilihan antibiotik yang tepat sangat menentukan pada kesembuhan pasien, karena tidak semua antibiotik dalam uji sensitifitas cocok untuk terapi demam tifoid.

Hasil biakan darah dengan metoda Bac-tect positif Salmonella typhi dijumpai pada $16 \%$ pasien (31 pasien dari 248 penderita demam tifoid anak pada tahun 2004). Hal ini dapat disebabkan oleh syarat pengambilan spesimen untuk Salmonella typhi yang kurang tepat. Sangat penting pengambilan spesimen darah sebanyak minimal 1-2 ml pada usia anak untuk mendapatkan angka positif sesuai $1 \mathrm{ml}$ cairan sumsum tulang pada spesimen biakan. Biakan sumsum tulang berguna dalam evaluasi lama sakit dan keberhasilan terapi antibiotik. Apabila menggunakan standar agar untuk kultur, maka salmonela dapat diisolasi pada $30-90 \%$ kasus demam tifoid. Kegagalan kultur dapat disebabkan oleh gagalnya mempertahankan suhu antara $15-40^{\circ} \mathrm{C}$ selama transportasi spesimen, metoda laboratorium yang tidak adekuat dan pemberian antibiotik sebelumnya. ${ }^{2,5}$

Uji serologi Widal seperti semua hasil laboratorium harus diinterpretasikan dengan bijak. Tanda-tanda klinis pasien harus lebih diutamakan daripada reaksi Widal yang positif karena sebagian besar anak Indonesia mempunyai reaksi Widal positif tanpa menderita demam tifoid. ${ }^{3} \mathrm{Hal}$ ini merupakan fenomena proteksi yang unik karena imunitas terhadap demam tifoid didapatkan dari kebiasaan jajan makanan di pinggir jalan, yang mungkin telah terkontaminasi S. typhi. Serologi Widal positif dapat disebabkan oleh pemberian vaksinasi anti-tifus pada anak usia di atas 2 tahun., ${ }^{2,6}$

Uji Widal hanya berguna bila dilakukan pemeriksaan secara serial, terjadi kenaikan titer antibodi $\mathrm{O} 1 / 320$ atau titer antibodi $\mathrm{H} 1 / 640$, atau terjadi kenaikan titer $\mathrm{O} 4$ kali dari pemeriksaan yang pertama dengan jarak pemeriksaan satu minggu. Bila nilai titer di bawah nilai yang telah ditentukan termasuk dalam kategori negatif. ${ }^{7}$ Di RSAB Harapan Kita nilai Widal positif bila titer $\mathrm{O}=1 / 160$ atau terjadi kenaikan titer $\mathrm{O} 4$ kali dari pemeriksaan yang pertama dengan jarak pemeriksaan satu minggu. Bila nilai titer di bawah dari nilai yang telah ditentukan termasuk dalam kategori negatif.

Pada penelitian ini dalam kurun waktu 1 tahun dijumpai 238 pasien demam tifoid, dan dilakukan uji Widal serta uji Bac-tect (Tabel 1). Sensitivitas uji Widal terhadap uji Bac-tect sebagai baku emas adalah 58,0\%, atau hanya 58,0\% di antara pasien demam tifoid dapat dideteksi dengan uji Widal. Spesifisitas uji Widal terhadap

Tabel 1. Perbandingan hasil pemeriksaan uji Widal terhadap uji Bac-tect

\begin{tabular}{lccc}
\hline & Bac-tect $(+)$ & Bac-tect $(-)$ & Jumlah \\
\hline Widal (+) & 18 & 99 & 117 \\
Widal (-) & 13 & 108 & 121 \\
& 31 & 207 & 238 \\
\hline
\end{tabular}


uji Bac-tect adalah 52,1\%, menunjukkan bahwa demam tifoid dapat disingkirkan hanya pada 52,1\% pasien dengan uji Widal negatif. Sensitifitas dan spesifisitas tersebut tidak memadai, sehingga uji Widal disini tampaknya bukanlah uji yang baik dalam menegakkan diagnosis demam tifoid. Kelemahan uji Widal adalah antibodi tidak muncul di awal penyakit, sifat antibodi sering bervariasi dan sering tidak ada kaitannya dengan gambaran klinis penyakit, dan dalam jumlah yang cukup besar (15\% atau lebih) tidak terjadi kenaikan titer $\mathrm{O}$ bermakna. ${ }^{8}$

Sebagian besar pasien sudah mendapatkan antibiotik per oral sebelum perawatan di rumah sakit, tetapi hanya 6 dari 31 yang diduga demam tifoid pada saat kunjungan ke dokter beberapa hari sebelum masuk rumah sakit dan mendapat antibiotik per oral yang biasa dipakai untuk terapi demam tifoid. Lebih dari $90 \%$ pasien demam tifoid mendapat pengobatan antibiotik per oral di rumah, istirahat cukup dan kontrol ke dokter. Pasien dengan gejala muntah yang berkepanjangan, diare berat atau kembung yang berlebihan membutuhkan perawatan di rumah sakit serta pemberian antibiotik intravena. ${ }^{2}$

Komplikasi terjadi pada 7 dari 31 pasien demam tifoid pada penelitian kami, terdiri dari pneumonia 3 dari 31 pasien dan perdarahan saluran cerna 4 dari 31 pasien. Secara keseluruhan sekitar 10\% - 15\% pasien demam tifoid akan mengalami infeksi yang berat. Faktor - faktor yang dapat mempengaruhi hal tersebut adalah lama sakit sebelum terapi antibiotik, pilihan antibiotik, strain bakteri yang virulen, jumlah inokulasi, riwayat vaksinasi anti-tifus sebelumnya atau kondisi imunokompromais. Komplikasi yang tersering adalah perdarahan saluran cerna, perforasi intestinal dan tifoid ensefalopati. Perdarahan saluran cerna terjadi sekitar 10\% - $20 \%$ dari kasus tifoid, disebabkan oleh erosi dari Peyer's patch dan mengenai pembuluh darah intestinal, dengan gejala klinis occult blood atau melena. Pada anak, lebih sering terjadi komplikasi pneumonia dibandingkan usia dewasa. ${ }^{2}$

Jenis antibiotik yang terbanyak digunakan dalam penelitian ini adalah ceftriaxone (18 kasus), diikuti oleh chloramphenicol (16 kasus), sisanya adalah cefotaxime, meropenem dan ceftazidime, masing-masing 1 kasus. Pada 7 kasus terjadi penggantian antibiotik chloramphenicol dan ceftriaxone, atau sebaliknya. Oleh karena itu peneliti lebih menekankan pembahasan tentang antibiotik yang pada pemberian dua antibiotik yang terbanyak digunakan.

Dijumpai 22 kasus demam tifoid mendapat antibiotik dengan dosis tepat selama perawatan. Rata- rata lama rawat adalah $(6,8 \pm 2,63)$ hari untuk pasien yang mendapatkan antibiotik dengan dosis tepat. Dijumpai 1 pasien dengan lama rawat cukup pendek yaitu 3 hari. Pada pasien ini sudah mendapatkan antibiotik per oral cefixime sebelum perawatan. Disamping itu dijumpai 7 pasien mendapat antibiotik selama perawatan dengan dosis kurang dibandingkan protokol yang berlaku. Rata-rata lama rawat adalah $(6,6 \pm 1,33)$ hari untuk pasien yang mendapatkan antibiotik dengan dosis kurang. Tampaknya tidak ada perbedaan yang nyata antara rata-rata lama rawat dan ketepatan dosis antibiotik yang diberikan. (Tabel 2)

Tabel 2. Rata-rata lama rawat terhadap ketepatan dosis antibiotik intravena

\begin{tabular}{lc}
\hline \multicolumn{1}{c}{$\begin{array}{c}\text { Pemberian antibiotik } \\
\text { berdasarkan dosis }\end{array}$} & $\begin{array}{l}\text { LOS* (hari) } \\
\text { Mean } \pm \text { SD }\end{array}$ \\
\hline Dosis tepat & $6,8 \pm 1,94(4,86-8,74)$ \\
Dosis kurang & $6,6 \pm 1,33(5,27-7,93)$ \\
\hline
\end{tabular}

LOS $^{*}=$ length of stay

Terdapat 1 pasien dengan lama rawat terpendek yaitu 3 hari karena pulang paksa, dengan terapi ceftriaxone dosis kurang. Pada pasien ini terjadi relaps 1 bulan setelah rawat. Hal ini sesuai dengan definisi relaps yaitu timbulnya kembali demam dan gejala klinis demam tifoid dalam 30 hari setelah terapi yang penuh disertai dengan isolasi $S$. typhi dari darah, atau $2-3$ minggu setelah turunnya demam. ${ }^{2,5}$ Pada penelitian kami ditemukan seluruhnya 1 kasus relaps dari 31 pasien. Tidak terjadi relaps pada 3 pasien yang masing-masing diberi antibiotik meropenem, ceftazidime dan cefotaxime. Angka relaps lebih rendah dibandingkan dengan angka relaps yang dilaporkan dalam literatur yaitu sekitar 5\% - 15\% pada pasien yang mendapatkan terapi ceftriaxone, dengan relaps secara klinis maupun ditemukannya kembali isolat $S$. typhi dalam darah, ${ }^{2,5,9,10}$ Pada umumnya dengan gejala klinis relaps lebih ringan. ${ }^{2}$ Pada penelitian Frenck $\mathrm{dkk}^{5}$, terapi dengan azithromycin per oral $(20 \mathrm{mg} / \mathrm{kg}$ per hari; dosis maksimal $1000 \mathrm{mg} /$ hari, dosis tunggal selama 5 hari) tidak terjadi relaps. Aktivitas azithromycin secara in vitro cukup baik terhadap berbagai patogen enterik, mempunyai penetrasi baik ke hampir seluruh jaringan, serta konsentrasinya dalam makrofag dan neutrofil mencapai $>100$ kali lebih tinggi dibandingkan dalam serum., ${ }^{5,11}$

Pada penghitungan rata-rata lama rawat terdapat 1 pasien dengan lama rawat yang sangat panjang yaitu 15 hari, sehingga dikeluarkan dari penghitungan. Pada pasien 
ini diagnosis awal tidak diduga suatu demam tifoid karena gejala klinis maupun hasil laboratorium darah tepi tidak mendukung. Pada minggu pertama gejala klinis tifoid tidak khas. Demam tifoid hampir tidak pernah dimulai dengan demam tinggi pada hari pertama sampai ketiga. Demam akan terus berlanjut dan pada hari ke 5-6 menjadi lebih tinggi, sampai tercapai suhu tertinggi sesudah itu yang merupakan gejala lebih penting untuk menduga adanya demam tifoid. Demam tinggi yang terjadi sampai $4-5$ hari, tanpa tanda-tanda infeksi bakteri yang jelas, lebih dari $90 \%$ kemungkinannya adalah infeksi oleh virus, dan tidak membutuhkan pemberian antibiotik. ${ }^{2}$ Keputusan untuk memberikan terapi antibiotik empiris sangat bergantung pada pertimbangan klinis dokter (clinical judgment). ${ }^{2}$ Pada kasus ini meskipun diberikan ceftriaxone selama 5 hari pada minggu kedua sakit, tetapi dosis $<75 \mathrm{mg} / \mathrm{kg}$, sehingga respons klinis tidak baik dan terapi dilanjutkan dengan chloramphenicol dengan dosis tepat dan memberikan respons klinis yang baik. Demam tifoid pada daerah endemis jika demam berlangsung lebih dari 1 minggu seperti pada kasus ini, bahkan pada hari ke 5 jika terdapat gejala toksemia yang berat memerlukan pertimbangan serius. ${ }^{2}$

Pada penelitian kami dijumpai 2 orang pasien dengan lama rawat sangat panjang yaitu 15 hari. Pada kedua kasus tersebut diagnosis awal tidak diduga demam tifoid, sehingga diberikan antibiotik intravena yang tidak sesuai untuk terapi demam tifoid. Diagnosis yang tepat dan diikuti dengan pemberian antibiotik dibutuhkan untuk memperpendek lama sakit dan mencegah komplikasi. ${ }^{12}$ Diagnosis klinis demam tifoid sangat bervariasi, dari demam ringan dengan morbiditas kecil hingga toksemia dan berhubungan dengan komplikasi pada berbagai sistem organ. Pada anak usia $<5$ tahun, demam tifoid dapat ringan dan menyerupai sindrom infeksi oleh virus. $\mathrm{Di}$ area endemis seperti Indonesia, diagnosis awal dapat keliru seperti pada kasus ini, disebabkan oleh gejala nonspesifik seperti diare dan muntah, hepatomegali, splenomegali atau gejala gangguan respirasi. Karena itu penyakit ini harus dibedakan dari demam berdarah dengue, malaria, tuberkulosis, sepsis akibat patogen bakterial yang lain atau anicteric hepatitis. ${ }^{2}$

Dijumpai 6 orang pasien yang mendapat terapi awal dengan chloramphenicol pada penelitian kami, tetapi kemudian dalam perawatan dipertimbangkan penggantian antibiotik dengan ceftriaxone. Hal ini dapat diterangkan oleh Bahn dan Bhatnagar, ${ }^{2}$ bahwa chloramphenicol sebagai pilihan lini pertama, kurang efektif dibandingkan dengan ceftriaxone dan terdapat risiko terjadinya persistensi $S$. typhi pada sumsum tulang, bahkan terhadap isolat yang sensitif 100\% terhadap chloramphenicol. Hanya 1 pasien yang mendapatkan ceftriaxone sebagai pengganti chloramphenicol karena jumlah leukosit <2000/ul.

Dijumpai 1 kasus mendapat terapi awal dengan ceftriaxone pada penelitian kami, tetapi pada hari ke 3 perawatan dipertimbangkan penggantian antibiotik dengan chloramphenicol. Ceftriaxone kadang-kadang menimbulkan gejala drug fever ditandai dengan demam yang persisten lebih dari 3 hari ${ }^{13}$ seperti pada kasus ini. Sebaiknya dokter mempertimbangkan hal ini dan tidak terburu-buru mengganti dengan antibiotik yang lain.

Grafik korelasi di bawah menggambarkan korelasi antara length of stay (LOS) dengan dosis antibiotik. Kelompok A adalah pasien demam tifoid yang mendapatkan chloramphenicol $(\mathrm{n}=9)$, dan kelompok $\mathrm{B}$ adalah pasien yang mendapatkan ceftriaxone $(\mathrm{n}=$ 11). Kelompok yang mendapat terapi antibiotik chloramfenicol pada awal perawatan dan kemudian diganti dengan ceftriaxone atau sebaliknya tidak dicari korelasinya dengan dosis (Gambar 1).

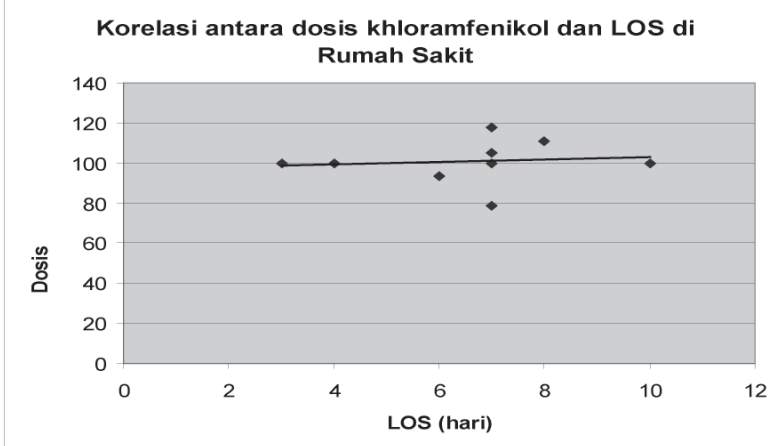

A) Kelompok chloramphenicol

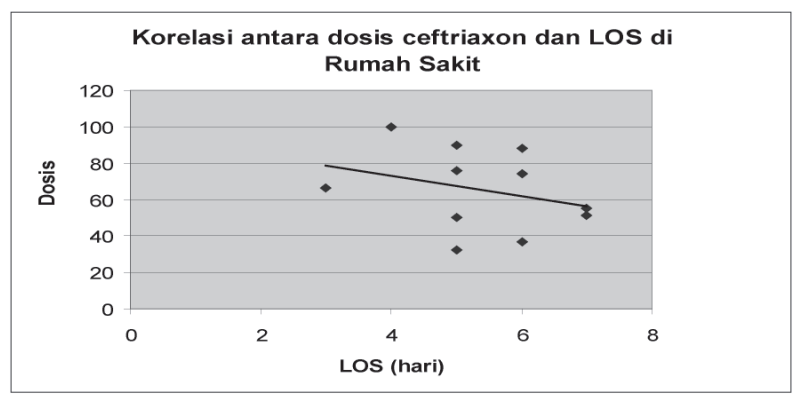

B) Kelompok ceftriaxone

Gambar 1. Korelasi antara lama rawat atau length of stay of stay (LOS) dengan dosis antibiotik intravena 
Pada kelompok pasien yang hanya mendapat chloramphenicol saja, tampak garis mendatar. Pada penelitian kami, ternyata pada seluruh pemberian antibiotik ini dosis yang diberikan tepat sesuai protokol dan sebagian besar dengan dosis $100 \mathrm{mg} /$ kg per hari (7 dari 9 pasien). Sedangkan pada kelompok pasien yang hanya mendapat ceftriaxone saja, tampaknya seakan-akan makin kecil dosis yang diberikan, justru lama rawat memendek. Hal ini mungkin disebabkan oleh pengaruh antibiotik per oral sebelum dirawat atau pasien dipulangkan terlalu dini. Sesuai kepustakaan, sebaiknya pasien demam tifoid mendapatkan antibiotik intravena hingga demam turun sekitar 5 hari, atau lama pemberian antibiotik paling tidak sesuai dengan protokol yang berlaku. ${ }^{2}$

Pada kelompok anak yang hanya mendapat terapi ceftriaxone saja mempunyai rata-rata length of stay (LOS) yang paling pendek yaitu 5,4 hari, diikuti 6,6 hari pada anak yang hanya mendapat terapi chloramphenicol saja. Pada kepustakaan disebutkan bahwa cepatnya darah menjadi steril setelah terapi dengan ceftriaxone berhubungan dengan tingginya kadar di dalam serum pada pemberian $75 \mathrm{mg} / \mathrm{kg}$ intravena. Hal ini juga disebabkan karena antimikroba yang bekerja pada dinding sel bakteri cenderung akan membunuh bakteri lebih cepat, dibandingkan dengan antimikroba yang kerjanya pada ribosom. ${ }^{5}$ Sedangkan kelompok yang men- dapat terapi chloramphenicol kemudian dilanjutkan dengan ceftriaxone atau sebaliknya mempunyai ratarata LOS yang terpanjang yaitu 8,6 hari. Penggantian terapi antibiotik pada kelompok ini disebabkan terjadi komplikasi atau tidak respon dengan antibiotik yang pertama, sehingga lama rawat memanjang. (Gambar 2)

Penelitian kami mempunyai beberapa keterbatasan. Penelitian ini dilakukan pada kurun waktu yang pendek yaitu 1 tahun, dengan sampel 31 pasien. Dibutuhkan sampel penelitian yang lebih besar, lengkap, serta prospektif untuk dapat mengevaluasi keberhasilan dan kegagalan terapi, perbaikan klinis maupun mikrobiologis, kejadian relaps secara klinis dan mikrobiologis, serta mengevaluasi berbagai faktor yang dapat mempengaruhi lama rawat.

\section{Kesimpulan}

Pasien demam tifoid terbanyak pada penelitian ini anak laki-laki, pada kelompok usia 6-10 tahun. Sebagian besar pasien mendapat terapi antibiotik chloramphenicol dan ceftriaxone intravena. Dijumpai $18 \%$ pasien yang diduga demam tifoid pada saat kunjungan ke dokter beberapa hari sebelum masuk rumah sakit dan sudah mendapat antibiotik per oral yang biasa dipakai untuk terapi demam tifoid. Komplikasi terjadi pada 7 dari 31 pasien, terdiri dari

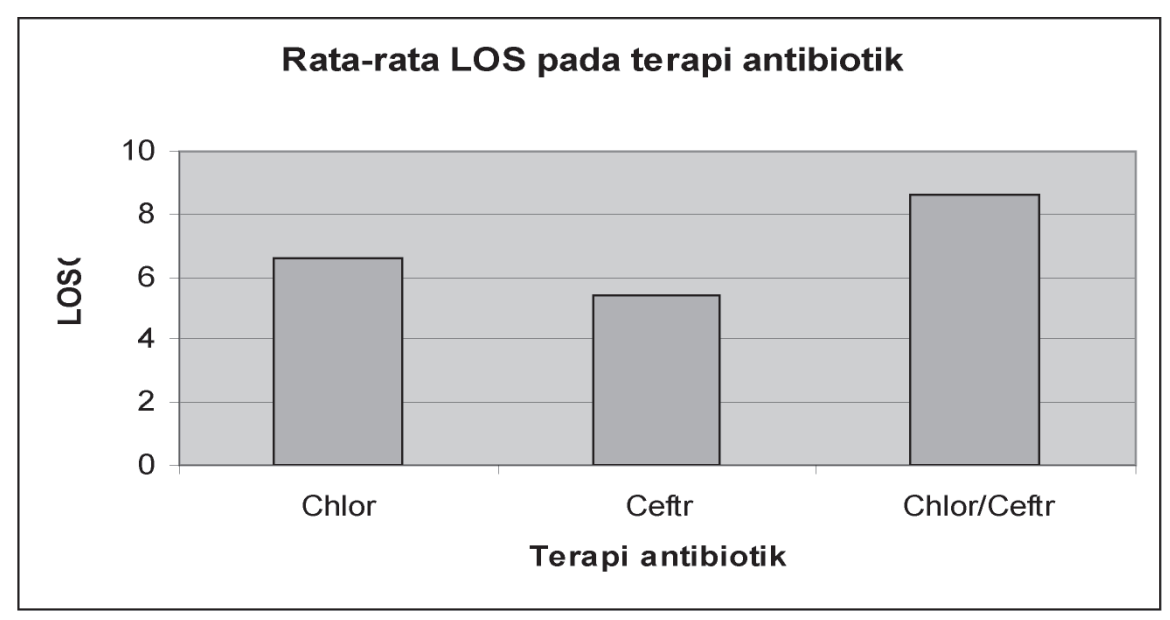

Gambar 2. Rata - rata lama rawat berdasarkan pemberian antibiotik intravena.

Chlor $=$ chloramphenicol, Ceftr $=$ ceftriaxone,

Chlor/Ceftr $=$ chloramphenicol $/$ ceftriaxone 
pneumonia 3 dari 31 pasien dan perdarahan saluran cerna 4 dari 31 pasien. Pemeriksaan serologi Widal tidak dapat menjadi parameter dalam menegakkan diagnosis demam tifoid. Tidak ada hubungan yang nyata antara pemberian antibiotik dengan dosis kurang dengan lama rawat pasien, tetapi tentunya masih banyak faktor lain yang dapat mempengaruhi lama rawat pasien.

\section{Daftar Pustaka}

1. Hadinegoro SRS, Tumbelaka AR, Satari HI. Pengobatan cefixime pada demam tifoid anak. Sari Pediatri 2001; 2:182-7.

2. Bahn MK, Bahl R, Bhatnagar S. Typhoid and paratyphoid fever. Lancet 2005; 366:749-62.

3. Darmansjah I. Widal positif belum tentu tifus. Didapat dari: http://www.kalbefarma.com/files/cerminduniakedokteran/ Majalah Intisari Mei 2000./01. Widal Positif Belum Tentu Tifus.2001.html. Diakses 26 Desember 2005.

4. Klaartje Kadang J. Pengenalan dini demam tifoid. Didapat dari: http://www.kalbefarma.com/files/ cerminduniakedokteran/03.Pengenalan Dini Demam Tifoid. 2003.124. html. Diakses 10 juni 2005.

5. Frenck RW, Jr, Mansour A, Nakhla I. Short-course azithromycin for the treatment of uncomplicated typhoid fever in children and adolescents. Clin Infect Dis 2004; 38:951 - 6 .

6. Connor BA, Schwartz E. Typhoid and paratyphoid fe- ver in travellers. Lancet Infect Dis 2005; 5:623-8.

7. Suyono S. Pemeriksaan laboratorium pada demam tifoid. Buku Ajar Ilmu Penyakit Dalam. Edisi ke-3 . Jakarta: Balai Penerbit Fakultas Kedokteran Universitas Indonesia, 2001. h. 435-41.

8. Hardi S, Soeharyo, Karnadi E. The diagnostic value of the widal test in typhoid fever patients. Dalam: Nelwan $\mathrm{RHH}$, penyunting. Typhoid fever: profil, diagnosis and treatment in the 1990's. Jakarta: Balai Penerbit FKUI, 1992. h.187-96.

9. Frenck RW, JR, Nakhla I, Sultan Y. Azithromicyn versus ceftriaxone for the treatment of uncomplicated typhoid fever in children. Clin Infect Dis 2000; 31:1134-8.

10. Lasserre R, Sangalang RP, Santiago I. Three-day treatment of typhoid fever with two different doses of ceftriaxone, compared to 14-day therapy with chloramphenicol: a randomized trial. J Antimicrob Chemother 1991; 28:765-72.

11. Wildfeuer A, Laufen H, Zimmermann T. Uptake of azithromycin by various cells and its intracellular activity under in vivo conditions. Antimicrob Agents Chemother 1996; 40:75-9.

12. Vollaard AM, Ali S, Widjaja S. Identification of typhoid fever and paratyphoid fever cases at presentation in outpatient clinics in Jakarta, Indonesia. Transactions of the Royal Soc of Trop Med and Hyg 2005; 99:440-50.

13. Hague R. Fever of unknown origin - investigation and management. Paediatrics 2001; 11:445-51. 